\title{
PAULO FREIRE em prosa
}

Caríssimos Leitores,

A e-Mosaicos - Revista Multidisciplinar de Ensino, Pesquisa, Extensão e Cultura do Instituto de Aplicação Fernando Rodrigues da Silveira (CAp-UERJ) traz, para o número 13, última edição do ano de 2017, a edição temática PAULO FREIRE - VIDA, PENSAMENTOS E PRÁTICAS - como celebração dos 20 anos de seu falecimento.

Esta edição, proposta pelas professoras Andrea Fernandes (UERJ) e Nima Spigolon (UNICAMP), está inserida na perspectiva do caráter interdisciplinar da revista e se ancora na importância de compartilharmos reflexões, saberes e fazeres que dialoguem com o pensamento e as concepções freireanas para a educação e para o ensino, com foco central na educação básica, constituindo-se como um espaço de análise e de reflexão crítica sobre a educação na atualidade.

Merecem destaque a Conversa-depoimento com o professor Carlos Rodrigues Brandão assim como o texto Opinião da professora Marli Ancassuerd (UNICAMP). Brandão relembra os muitos momentos em que viveu ao lado do amigo Paulo Freire desde antes dos tempos do exílio até os últimos anos de convivência. Já a professora Ancassuerd, relata algumas de suas andanças em África (por volta dos anos 1980) vinculadas ao trabalho político-pedagógico para formar alfabetizadores de adultos.

Em seguida, os artigos desta edição vêm dialogar com o legado de Paulo Freire, considerando as interfaces entre os espaçostempos de produção de conhecimento e os modos de fazer, bem como estimulam o diálogo entre as concepções freireanas de educação e suas contribuições para o desenvolvimento dos sujeitos aprendentes e, também, ensinantes a fim de potencializar as reflexões sobre caminhos trilhados e a serem trilhados pela escola que se insere e que se faz fundamental para a sociedade do século XXI e seus processos de transformação. As resenhas, por sua vez, trazem significativas sugestões para a ampliação do conhecimento sobre o autor e sua vida.

É oportuno dizer que esta edição, cuidadosamente organizada, é publicada em um ano diferenciado pelos imprescindíveis movimentos de resistência e de defesa da educação pública e de qualidade no Brasil. Nossa Universidade, a UERJ, esteve no centro da cena durante todo o ano - o que só nos fortalece como uma universidade com um amplo espaço de formação continuada, laica, inclusiva e de qualidade socialmente referenciada nos âmbitos do ensino, da extensão e da pesquisa acadêmica.

No mais, boa leitura e um ano de 2018 promissor!

Christiane de Faria Pereira Arcuri

Editora da e-Mosaicos - Revista Multidisciplinar de Ensino, Pesquisa, Extensão e Cultura do Instituto de Aplicação Fernando Rodrigues da Silveira (CAp-UERJ) 